\title{
Correction to: Puberty Blockers and Suicidality in Adolescents Suffering from Gender Dysphoria
}

\author{
Michael Biggs ${ }^{1}[$
}

Published online: 1 June 2021

(c) Springer Science+Business Media, LLC, part of Springer Nature 2021

\section{Correction to: \\ Archives of Sexual Behavior (2020) 49:2227-2229 https://doi.org/10.1007/s10508-020-01743-6}

The Letter to the Editor "Puberty Blockers and Suicidality in Adolescents Suffering from Gender Dysphoria," written by Michael Biggs, was originally published electronically on the publisher's internet portal on 3 June 2020 without open access. With the author's decision to opt for Open Choice, the copyright of the letter changed on 17 May 2021 to $($ C The Author(s) 2021 and the Letter is forthwith distributed under a Creative Commons Attribution 4.0 International License, which permits use, sharing, adaptation, distribution, and reproduction in any medium or format, as long as you give appropriate credit to the original author and the source, provide a link to the Creative Commons license, and indicate if changes were made. The images or other third party material in this article are included in the article's Creative Commons license, unless indicated otherwise in a credit line to the material. If material is not included in the article's Creative Commons license and your intended use is not permitted by statutory regulation or exceeds the permitted use, you will need to obtain permission directly from the copyright holder. To view a copy of this license, visit http://creativecommons. org/licenses/by/4.0/.

Open Access This article is licensed under a Creative Commons Attribution 4.0 International License, which permits use, sharing, adaptation, distribution and reproduction in any medium or format, as long as you give appropriate credit to the original author(s) and the source, provide a link to the Creative Commons licence, and indicate if changes were made. The images or other third party material in this article are included in the article's Creative Commons licence, unless indicated otherwise in a credit line to the material. If material is not included in the article's Creative Commons licence and your intended use is not permitted by statutory regulation or exceeds the permitted use, you will need to obtain permission directly from the copyright holder. To view a copy of this licence, visit http://creativecommons.org/licenses/by/4.0/.

Publisher's Note Springer Nature remains neutral with regard to jurisdictional claims in published maps and institutional affiliations.

The original article can be found online at https://doi.org/10.1007/ s10508-020-01743-6.

Michael Biggs

michael.biggs@sociology.ox.ac.uk

1 Department of Sociology, St Cross College, University of Oxford, 42 Park End Street, Oxford OX1 1JD, UK 